突に対する強度をどら規定すべきかを決めかねた，二次 構造でもあり，破壊様式からしても致命的な事故にはな りそうにないため, 結局はメンテナンスコストとのトレ 一ドで決まると思われるが，民間機の滑走中の異物飛散 の程度, 確率などのデータ取得という点からまず解決せ ねばならない。

複合材構造の採否のキーポイントは信頼性とコストで あるが、コストは各社ごとにその算定基準が異なり，か つ対外秘的要素が強い。したがって内訳の推定值が提出 されることが少なく，そのままでは各種構造，成形方式 の横通しの比較，コスト分析がむずかしいため，59 年度 からは Northrop による方式)を統一法として用いるこ とにしている.

材料の改良による信頼性の向上，構造効率の向上に伴 い，今後ますます製品コスト低減の研究が指向される が，複合材の場合，素材費が大きなウェイトを占める. この点では素材メーカのいっそらの努力を期待したい.

\section{8. 運用技術の研究}

メーカサイドから見た運用技術の研究項目は運航時の 非破壊検查技術と修理であろう．残念ながらこれらはす べて今後の課題として残されている.工場における非破 壊検査は既製の超音波 Cスキャン，軟X線などを利用し ているがいずれも大変な工数・費用がかかり，操作・判 読に至るまでの自動化が望まれる。これらの方式を時間
に限りのあるエアラインの整備にそのまま適用すること はできない, 修理にしても方法, 設備, 修理法, コスト 等，結果いかんによっては設計基準・材料選定にはねか えるものであり，早急な検討を要するものである.

\section{9.おわりに}

YXX は先進複合材とアルミニウム・リチウム合金と いら二大新素材をいかに活用するかといら構造設計上の 難問を抱えているといっても過言ではなく，材料選定が 構造様式，製造方式のすべてを変えてしまら立場にあ り，構造開発研究はいままでにない慎重さと掘り下げが 必要である．この観点からすでに JADC は航技研の方 方との技術連絡会を持って有益な助言・助力をいただい ているが，今後さらに広く他分野の研究者諸氏のご協力 を打願いしたいと思う。

\section{参考 文 献}

1) J.T. Quinlivan \& D.T. Lovell : ICAS-82-2.2.1 (1982).

2) J.H. Stahnes, Jr., N.F. Knight, Jr. \& M. Rouse : AIAA 82-0777 (1982).

3) B.L. Agarwal : AIAA 82-0746 (1982).

4) H.L. Bohon : NASA CP 2251, "Advanced Materials Technology," compiled by C.P. Blankenship \& L.A. Teichman (1982).

5) Northrop Corporation: AFFDL-TR-76-87(1976).

\title{
鋼繊維補強コンクリート利用の現状
}

\section{魚本 健 人*}

\section{1. は し がき}

現在，瀻維を利用したセメントコンクリート系複合材 料には種々のものがあり，利用の仕方もさまざまであ る.また，使用されている瀻維としては，鋼緘維，ガラ ス緘維，カーボン繊維，ポリエチレン㵶維などがある. なかでも，今日建設分野において，構造用材料として最 も一般的に使用されているのは鋼繊維であり，セメント

* Taketo Uомото : 東京大学生産技術研究所 (106 東宗都港区六本木 7-22-1)
コンクリート中に短鋼瀻維を分散させた鋼繊維補強コン クリート (steel fiber reinforced concrete : SFRC) と しての利用が多い.

SFRC に対する関心が高まったのは, 1963 年に発表さ れた Romualdi らの研究1が発端となっている．その理 由は, 従来, コンクリートの最大の欠点であるとされて いた脆性的な破壊を，鋼繊維で補強することにより防止 することができると説明されていたからである，その 後，SFRCに関する研究および開発は, 1969 年頃からの アメリカに扣ける鋼繊維の量産技術の開発によって世界 
的に行なわれるよらになった. しかし，諸外国における その後の研究は基礎的な研究が中心となり，実用化に関 する研究はわが国が先行するようになった。

わが国では, 1970 年頃から各研究機関で SFRC に関 する研究開発が行なわれ, 基礎的な研究のみならず実用 化を目的とした多くの研究が実施された 新しい鋼繊維や製造方法の開発, 実構造物へ適用する場 合に不可欠な SFRC の配合方法や試験方法に関する研 究，各種構造物に対する適用方法等の開発，研究が行な われ，多くの構造物に適用された。今日では，わが国は 世界でも最も多量の SFRC を利用している国の一つに なっている.

本文では，今日このように多量に用いられるようにな った SFRC の利用の現状について，扣もにわが国を中 心として概説する.

\section{SFRC の特性と適用対象構造物}

SFRC を使用する目的としては種々のものがあるが， 今日，実際の構造物に使用されている SFRC は，扣も に鋼繊維とコンクリートとの力学複合を目的としたもの で，普通コンクリートに比べて優れている次のような利 点を活用している場合が多い。

（1）高い曲げ強度, 引張り強度, 剪断強度等の利用

(2) 高いひび割れ発生に対する抵抗性の利用

（3）高い勒性や耐衝撃性等の利用

この他にも遠心形成されたヒューム管のように，鋼繊 維の配向扣よび分散を制御して鉄筋と同じよらな補強効 果を目的として使用する場合や，鉄筋と併用して一つの 構造体として使用する場合もある．以下に，現在比較的 多く使用されている適用対象構造物と SFRC の特性と の関係について説明する.

SFRC が普通コンクリートに比べ, 曲げ強度, 引張り 強度や剪断強度が高いことは, すでに多くの研究者によ って明らかにされている. 図 1 は, 岡村3)が行なった実 験結果を示したものである。この図より， SFRCの繊維 混入率が $0.5 \%$ 程度ではあまり変化がないが, $2 \%$ 程度 まで繊維混入率を高めれば普通コンクリートの約 2 倍の 強度となることがわかる，このため, 纎維混入率の高い SFRCを使用すれば，普通コンクリートに比べ，構造物 の断面積を減少することが可能となる。これは，とくに 軽量化を図ることが重要な構造物や，断面減少によるメ リットの大きな構造物などでは重要視される特性であ る。

軽量化を図ることが重要な構造物としては橋梁の上部

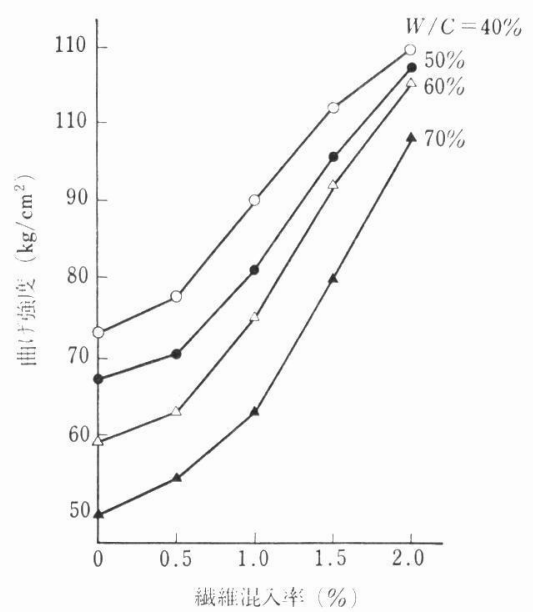

図 1 SFRC の曲げ強度と繊維混入率との関係3) $\left(\begin{array}{l}\text { 鋼繊維 : } 0.5 \times 0.5 \times 30 \mathrm{~mm} \text {, 粗骨材の最大寸 } \\ \text { 法 : } 15 \mathrm{~mm} \text {, 供試体 : } 10 \times 10 \times 40 \mathrm{~cm}\end{array}\right)$

工などがある。この上部工の軽量化が行なえれば，スパ ンの増大や上部工を支持している下部工をより小さなる のにすることができ，構造物全体としてより経済的なも のにすることができる．

一方，断面減少によるメリットの大きな構造物の一つ としてトンネルのライニングが上げられる. 図 2 に示し たよらにトンネルのライニング材として SFRC を用い ると, 普通コンクリートにくらベライニング厚さを減ら すことが可能で，トンネルの掘削断面積等を減らすこと になる、結果的に, トンネルの掘削量, 搬出土砂量, 打 設コンクリート量等多くの施工量が減少することにな り, 経済的にも×リットが多い.

図3は，小林ら ${ }^{4)}$ が行なった SFRC のひび割れ拘束 性と緎維混入率との関係を示したものである。この図か

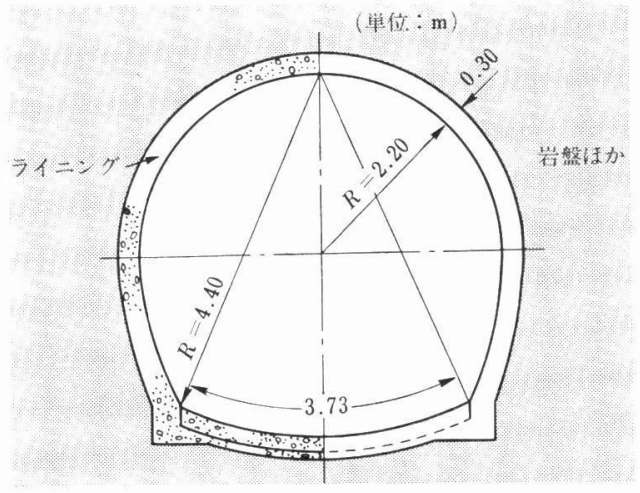

困 2 トンネル断面の一例 


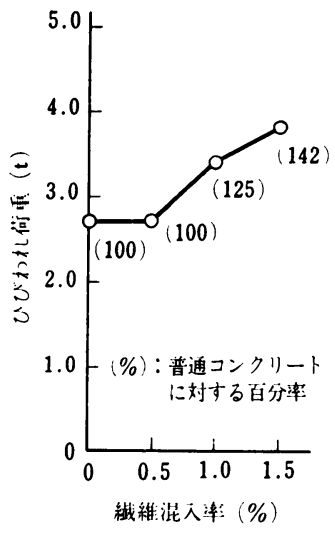

a

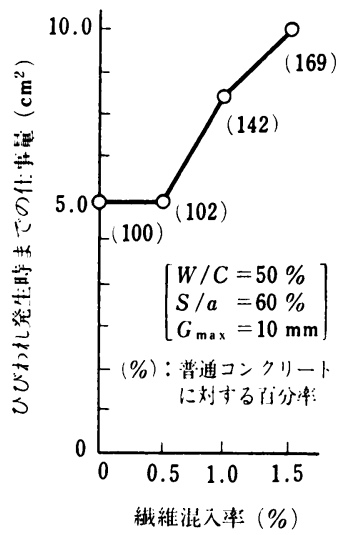

(b)

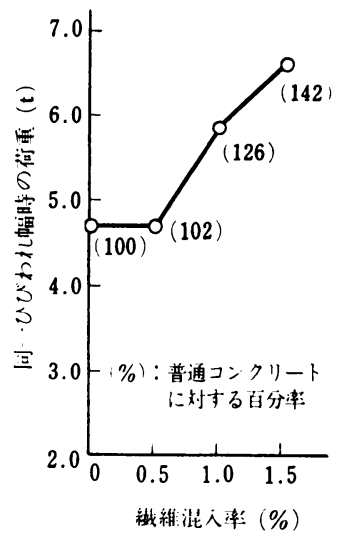

c)

図 3 ひび割れ拘束性能と繊維混入率との関係 ${ }^{4}$

ら明らかなように, SFRC は,ひび割れ発生に対する抵 抗性もひび割れ拘束性も，ある限界の㵶維混入率 $(0.5 \%$ 程度）が存在し, その後は, 㵶維混入率とともにほぼ直 線的に增大する.この傾向は上記の曲将強度の場合と同 じである，もし，SFRC のひび割れ発生に対する抵抗性 を利用する場合には, ある限界繊維混入率以上の繊維混 入率を有する SFRC とすることが必要である.

SFRC のひび割れに対する抵抗性が大きいことは，構 造物の耐久性を高めることになるため，ダム，河川構造 物等の水密性などを要求される構造物や厳しい環境に設 けられる構造物に利用されている. とくに，近年のよう にコンクリート構造物の耐久性が問題とされるようにな ると，より多くの構造物に適用される可能性がある.

図 4 は，土木学会の試験方法によって行なった曲げ靶 性係数と瀻維混入率との関係を示したものである5)。曲 げ靶性係数は，図 5 に示したように曲げ載荷時における 応力撓み曲線から求めるもので, 所定の撓み量に達する までの吸収エネルギに比例する.この図から明らかなよ

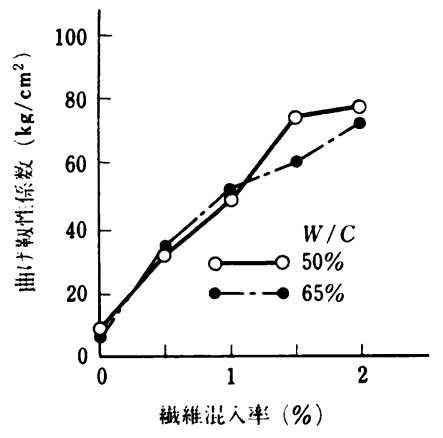

図 4 SFRC の曲げ靱性係数と㵶維混入率との関係 ${ }^{5}$

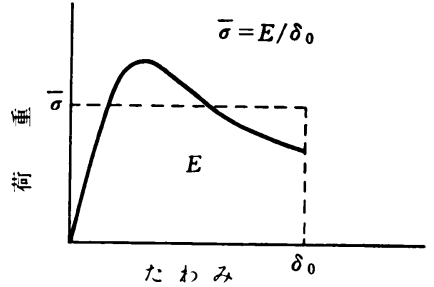

因 5 曲げ靱性係数の求め力 ${ }^{7}$ $\delta_{0}=l / 150, l:$ スパン

らに, SFRC の緎維混入摔が增大すると我躍的に吸収エ ネルギが増加している.

SFRC の耐衝撃性や靱性が優れていることを考虑し て，空港舗装のような大きな集中荷重が作用する構造物 や，二次製品などの割れや欠けを防止することを目的と したり，掘削のり面保護工などの破壊に対する安全性や 耐久性の向上を目的としても利用されている. 二次製品 などは，使用時においても簡単にひび割れや欠けが生じ にくい性能を有していることが望ましく，場合によって は久け等の生じやすい角部たけに SFRC を使用する場 合もある．また，掘削のり面保護工では，普通コンクリ 一トに比べ SFRC は高い変形能力を有していることか ら，のり面のずれ等に対しても優れた効果を発揮する.

\section{3. わが国における SFRC の利用}

\subsection{SFRC の使用量}

わが国ではすでにかなり多くの構造物に SFRC が使 用されており，現在，わが国で使用されている SFRC の量は, 年間 4 万 $\mathrm{m}^{3}$ 以上であると推定される. しか 
し，このように使用量が多くなったのは 1980 年代に入 ってからである。

SFRC に限らず新材料を建設材料, それも構造材料之 して一般的に利用するためには，材料そのものの性能が 一般的に熟められることばかりでなく，実構造物に適用 した場合の問題点の摘出と解明が必要となる。このた め, 1970 年代には実構造物への適用方法などの検討を含 めた試験的な利用が主であった。

1980 年代に入るとわが国では多くの指針，規準類が公 表され，それに伴いSFRC の利用量も増大した。すな わち, 昭和 55 年には日本トンネル技術協会6), 昭和 58 年には土木学会7), 昭和 59 年には日本コンクリート工学 協会8) 拈よび日本建築学会9) から各種の報告ならびに指 針類が次々と発表され，実用のための規準類が整備され た.

図6 は, 昭和 54 年度を基準として (社)鋼材俱楽部が 調べた鋼緎維の推定利用量比率を年度別に示したもので ある. 参考のために同図に建設白書 (昭和 59 年版 ${ }^{10}$ に よる建設投資額比率の推移もあわせて㘠示してある。こ の网から明らかなよらに，鋼繊維の利用量は昭和 55 年 以降，急に増大しているが，これは上記の指針や規準類 が整備されたことが一つのきっかけになっているものと 思われる、しかし, 建設投資額が昭和 57 年以降減少寸 るにつれ, やや遅れた形で鋼緎維の利用量も減少へと転 じ, 昭和 57 年度以降は昭和 54 年度のほほ 2 倍程度に とどまっている，な执，鋼繊維の使用量增加率が建設投 資額増加率のほぼ 10 倍になっていることは, 今後建設 投資額が増大すれば，大きく増加する可能性があること を示唆しているものといえよう.

\subsection{SFRC の適用構造物と繊維混入率}

図 7 は，図6 の場合と同様に(社)鋼材俱楽部の資料に 基づきわが国に拈ける昭和 54 年から昭和 59 年まで の鋼繊維の適用構造物別割合を示したものである.この 図で特徴的なことは，次のと扣りである。

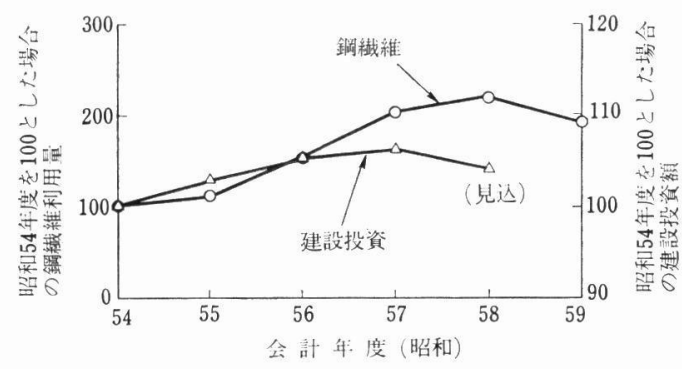

図 6 鋼繊維の利用量と建設投資額の推移

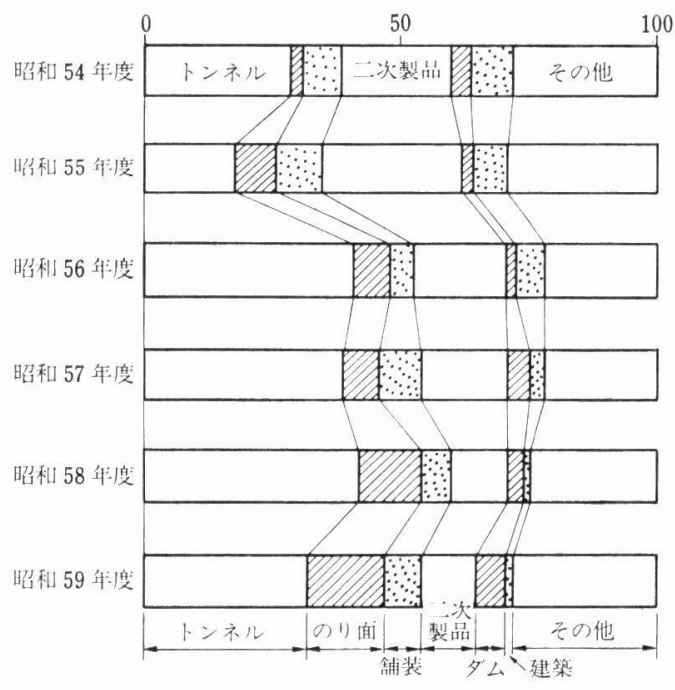

図7 鋼䋐維の利用分野別割合之年度別変化

(1) トンネルヘの適用が多くほほ $30 \%$ 以上を占めて いる.

（2）のり面吹き付忛への適用が年とともに増加してお り，昭和 58 年度では $18 \%$ 以上となっている。

（3）二次製品への適用は，昭和 55 年度まで多いにも かかわらずその後減少している。

(4) 建築構造物への適用は年とともに減少する傾向が 認められる。

（5）舗装，ダム等への適用はあまり変化していない.

これらの特徵からも明らかなよらに, SFRC はどちら かといえば, 従来無筋コンクリート構造とされていたも のや鉄筋量の少ないコンクリート構造物への適用が主と なっている。また，建築構造物への適用が減少している のは SFRC とするとコストが高くなることや, 表面に 現われた鋼瀻維が腐食し外観を損ならことなどが原因で 西ると思われる。なお，のり面やトンネルへの適用は,

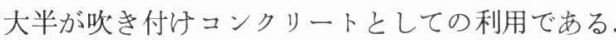

SFRC の通常の䋐維混入率は，体積で 0.5 から $2.0 \%$ の範囲である. 構造物別にどの程度の繊維混入率が用い られているかを示したものが図8である7、この図よ り, 繊維混入率の高い構造物は道路および橋面舗装であ り,トンネル, ダム, のり面等は少ない, 舗装の場合に は, SFRC が高い曲げ強度を有することを生かし，舗装 厚の低減等を考慮したためであると考えられる. トンネ ルやのり面の場合には, SFRCを吹さ付け施工すること が多いため, 施工上，高い繊維混入率としにくいこと等 


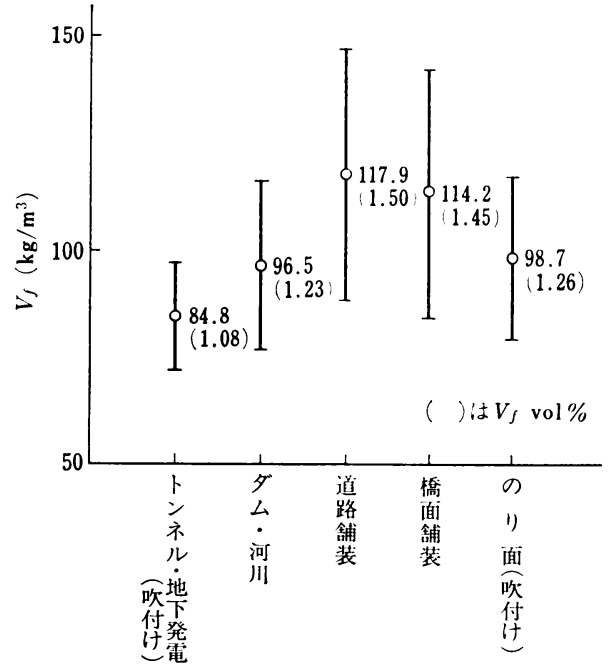

図 8 構造物別の鋼緎維混入量 ${ }^{7}$

が影響しているものと思われる．なお，建築構造物に関 してはその使用が多岐にわたっているために一概には いえないが，緘維混入率は $1 \%$ 程度であると推 定され る.

\section{4. 諸外国における SFRC の利用}

諸外国の SFRC に関する統計資料は，入手できてい ないので明瞭なことはいえないが，文献等に記述されて いることを以下に紹介する．

寸でに述べたように, 欧米諸国では 1970 年代から研 究活動が進められているものの, SFRC の実構造物への 利用に関する報告は少ない.SFRC の設計や施工に関す る指針や規準としては，米国の A.C.I. (American Concrete Institute) から 1984 年に発表されたもの11) が唯 一であるといえよう。

欧米諸国における，SFRCの利用に関する報告はわが 国ほど多くないためはっきりしないが，特徵的なこと は，国によって SFRC の適用対象構造物が異なってい ることである。

たとえば，米国では道路用のみならず空港の舗装， と くにオーバーレイへの適用例が多く，それも舗装厚さを 減らすためでなく, 強度を高め耐久年数を増加させるた めに用いるといら報告が出されている，一方，欧州では 舖装やトンネルのライニング等に多く用いられており， どちらかといえばわが国に近い使用がなされていると いえよう。これは，欧州諸国の自然条件がわが国に近い ためであると考えられる．また，オーストラリアなどで は，米国型の舗装ならびにオーバーレイへの適用が多い
と報告されている．

\section{SFRC の課題と今後の利用方法}

わが国ならびに諸外国において，SFRC がどのよらに 用いられているかを説明した. しかし， SFRC の使用量 が他の建設材料に比べそれほど多くはないことは，わが 国で年間に使用されるコンクリート量が 2 億 $\mathrm{m}^{3}$ 以上で あることからも明らかである.

この最大の原因は, SFRCのコストと得られるメリッ トとの関係がなかなか一致しない点であるといえよう。 SFRC は材料費たけげ普通コンクリートの 2 倍から 3 倍 となり, 施工費等を含めるとかなり高いものとなるが, それに見合った利用方法が確立されていないことであ る.

そこで，今後の SFRC の利用方法としては，コスト に見合った利用であって，たとえばいままであまり活用 されていない鉄筋を併用した構造物への利用や，力学複 合以外の複合材料としての活用方法などが考えられる. 以下に 2,3 の例を示す.

\section{1 鉄筋を併用した構造としての利用}

困 9 は, 普通鉄筋コンクリート梁と鋼㵶維補强鉄筋コ ンクリート梁の疲労試験結果を示したもので13), いずれ もスターラップ $(0.33 \%)$ を配してある. 図からも明ら かなように, SFRC 梁は普通鉄筋コンクリート梁に比べ 高い疲労強度を有している.これは普通鉄筋コンクリー ト梁が䇋断破壊となったのに対し，SFRCの梁ではいず れも曲げ破壊となったために生じた現象である.

図 10 は, スターラップ（腹鉄筋）のない鉄筋コンク リート梁の曲げ耐力が剪断スパン比 $(a / d)$ によってど ら変化するかを示したものである14). この図で特徴的な ことは，普通コンクリートの場合には $a / d$ が小さくな ると剪断破壊を生じやすくなり，最大曲げ耐力は大幅に

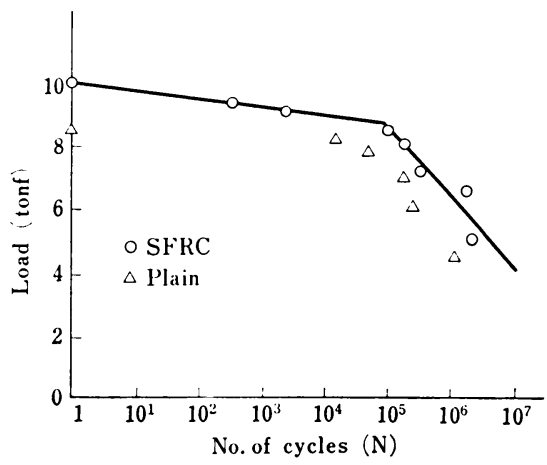

図 9 疲労試験結果の比較 ${ }^{13)}$ 


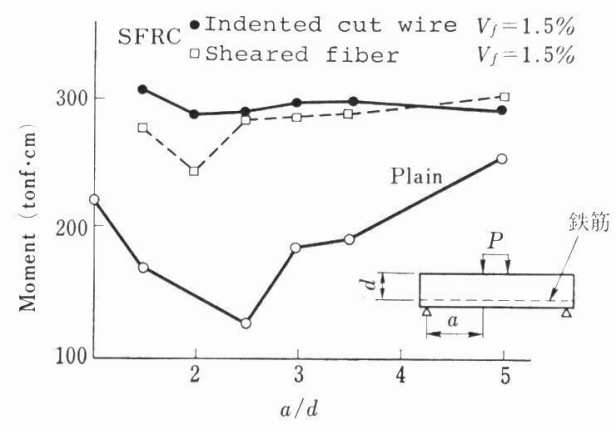

図 10 スターラップのない単鉄筋梁の最大曲げ耐力 比較 ${ }^{14)}$

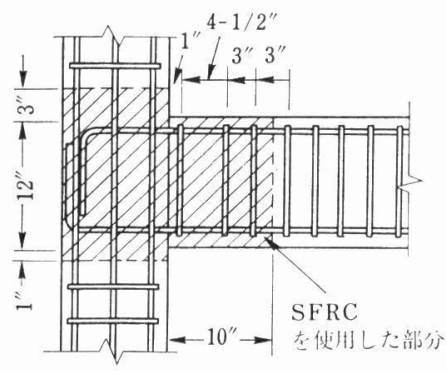

図 11 ハッチ部分を SFRC によって置き 換えた接合部 ${ }^{12}$

減少しているが，SFRC を鉄竻と併用した場合には㴗と んど耐力の低下が翏められないことである.

これらのことからもわかるよらに, SFRC は剪断強度 が高いだけでなくひび割れ発生後も応力の伝達が行なわ れるため，鉄筋を併用すると構造的にもより高い安全率 を有している，このよらな利用方法は今後, より重要と なろら、また, 図11に示すよらに, 鉄筋コンクリート構 造部材の接合部への適用方法などが報告されており 12), わが国の建築関係者に注目されている.

\section{2 防食材料および補修材料としての利用}

海洋環境下に設けられた構造物は，鋼構造物はもらろ んのことコンクリート構造物であっても内部の鉄筋は海 からの塩分の浸透によって腐食する. これを防止する 一つの方法として, SFRCを表面に被覆する方法が考え られる。

SFRC は，その構成材料であるセメントの働きによっ て高いアルカリ性を有しているだけでなく，ひび割れに 対する抵抗性が強いため，これを被覆材として用いれば 防食材として使用することが可能である。鋼材俱楽部が 海洋環境下に設けた鋼管の被覆材として SFRC を使用 した実験7では，10 年経過後も内部の鋼管表面に発錆が
認められなかったと報告している。な打，この場合表面 近傍の鋼繊維そのものに若干の腐食は認められている が, 繊維の寸法が小さく, 連続していないため, 形成さ れる腐食電池も小さく, 腐食量も小さかったものと考え られる。

補修材料としての利用は, 吹付けコンクリートとして 活用すれば，防食効果等も期待することがでさるので今 後有望であると考克られる。

\section{6. あと がき}

多くの新しい材料が開発されても，コストの問題や取 扱いの問題があると，なかなか実際の製品等には使用さ れない。建設材料の場合も，従来のコンクリートや鋼材 にとってかわるものがなかなか出現してこないが，材料 の特性を考虑して，らまく材料を生かすように構造設計 や材料設計を史施すれば，新しい材料を有効に使用する ことができる。

わが国の経済成長率が小さくなった今日，社会資本の 充丰ならびにその維持管理が重要視されるよらになる と, 耐久性や安全性を必要とする構造物などは SFRC のような高い靱性および耐久性を有する材料を活用する ことが大切になってくる．今後，SFRCもコストに見合 った適用方法が開発されるものと予想され，本文がその 一助となれば幸いである。

\section{参考 文 献}

1) J.P. Romualdi \& G.B. Batson : Proc. ASCE, 89, No. EM 3 (1963), 147-168.

2) 小林一輔：繊維補強コンクリート一特性と応 用一, オーム社, 東京 (1981).

3) 岡村雄樹: 日本大学学位論文 (1980).

4) 小林一輔, 趙 力采: 土木学会論文報告集, No. 300 (1980), 109-119.

5）魚本健人，西村次男：セメント技術年報，No. 36 (1982), 408-411.

6) 日本トンネル技術協会 : スチールファイバーコン クリートに関する調查研究報告書 (1980).

7) 土木学会 : 鋼繊維補強コンクリート設計施工指針 (案)、コンクリートライブラリー，第 50 号 (1983).

8) 日本コンクリート工学協会 : 繊維補強コンクリー トの試験方法に関する規準 (1984).

9）日本建築学会：スチールファイバーコンクリート 技術の現状 (1984).

10) 建設省編：昭和 59 年版建設白書, 大藏省印刷局 (1984).

11) ACI Committee 544: ACI J., 81, 2(1984), 
140-148.

12) C.H. Henegar : ACI SP-53 (1977), pp.371381.

13) R.K. ウイーララタナ, 魚本健人, 西村次男 : 第
39回土木学会年次学術講演会講演概要集 (1984), pp. 75-76.

14) T. Uomoto \& R.K. Weeraratne : Struct. Eng. Constr., 1 (1986), 521-531.

\section{日本複合材料学会誌（邦文誌）への論文投稿のすすめ}

日本複合材料学会誌（邦文誌）は年 6 回の刊行で, 各号に $3 \sim 4$ 編の邦文論文（研究論文, 研究ノート, 技術 資料）の掲載を予定しております，会員各位の積極的なご投稿をおすすめいたします。

致投稿資格 本会会員に限りますが，会員外の共同 研究者を含むことはさしつかえありません．

\section{愿稿の種類および制限頁数}

研究 論 文: 刷上り 6 ページ以内

研究ノート：刷上り 2 ページ以内

技術資料：刷上り 6 ページ以内

的投稿の申込み任意の用紙に著者名, 論文題目, 論文種目, 論文要旨 (400 字以内) および連絡先 等を記入のうえ下記宛郵送ください.

干113 東京都文京区湯島 2-30-9

学会誌刊行センター内

「日本複合材料学会誌」編集委員会

(TEL. 03-817-5825)
折返し，学会所定の原稿用紙（有料）をお送りい たします．論文作成の要領は原稿用紙の表紙裏面に 印刷してありますのでご参照ください.

\section{滺揭 載 料 無料}

别別料金

\begin{tabular}{ccccc}
\hline & 50 & 100 & 150 & 200 部 \\
\hline $1 \sim 2$ 頁 & 12,000 & 16,000 & 20,000 & 24,000 円 \\
$3 \sim 4$ & 18,000 & 22,000 & 26,000 & 30,000 \\
$5 \sim 6$ & 24,000 & 28,000 & 32,000 & 36,000 \\
7 & 40,000 & 45,000 & 50,000 & 55,000 \\
8 & 50,000 & 55,000 & 60,000 & 65,000 \\
\hline & (全表紙付, 購入義務最少 50 部)
\end{tabular}

